priority items.

In its programme for 1977, published in February, the Commission says it will concentrate on four basic 'priority themes': measures to combat water pollution; evaluation of measures to prevent the deterioration of the environment; an anti-waste campaign based on a policy to encourage materials recycling; and implementation of the international conventions on the Rhine and the Mediterranean. It says it will therefore send to the Council proposals for directives on, amongst other things, protection of underground water, the quality of water for agricultural use, notification of industrial activity involving dangerous substances (a lesson of Seveso), the discharge of various particularly harmful pollutants, and on anti-noise measures.

The Commission thus remains optimistic. Its work goes ahead under the auspices of the second action programme, which the Council meeting of last December unanimously approved, adding the undertaking that it would act on concrete proposals from the Commission within nine months of them being forwarded. That may prove to be a tall order, given the fundamental character of some of the issues still outstanding concerning the Community's environment policy. But the
Community and its policies are nothing if not resilient. And the large number of directives which have already gone through suggest that whole effort in the environmental field may have acquired a momentum.

That should allow some attack in the primary field of preventing and eliminating pollution and nuisances, where most attention has been concentrated. But managing the use of natural resources properly, controlling the ecological balance and economic growth, and generally protecting the biosphere --also aims of the EEC's second action programme-will plainly take a little longer.

\title{
Spreading the word
}

\section{David Spurgeon, recently in Asia, examines the growth of science writing there}

$T_{s c}^{\text {He }}$ $\mathrm{HE}$ business of writing about science for the mass media must have its ups and downs like any other business. Although it is difficult to judge without the evidence of a fullscale survey, it seems the trend in North America in recent years has been predominantly down. Editors no longer show the enthusiasm for science subjects that they did during the early post-Sputnik days and discussions have appeared in science writers' newsletters about the parlous state of their craft.

Some link the decline in interest to the scepticism-and in some measure, disillusionment-about the promise of science that followed the excesses of publicity associated with the US manned space programme, the development of nuclear power and 'wonder drugs' and other achievements. It seems a reasonable thesis; the earlier 'geewhiz' phase of science writing was followed not only by a much more critical and judgmental phase, but also by the birth of various anti-science movements and by 'consumerism' and 'environmentalism'.

An interesting contrast is found in the Third World, particularly in Asia, where (again to some extent subjectively) interest in science journalism seems definitely on the upswing. Mack Laing, a Canadian science writer and professor of journalism, writing in Depthnews Science Service, a weekly newsfeature service of the Press Foundation of Asia (PFA), put it this way in a recent article from Manila:

There is a burst of activity in Asia these days toward achieving a greater public understanding of science. Some-perhaps even most-Asian nations are just waking up to the need for more public apprecia tion of how science and technology can help national development. Other countries are going full blast on the idea. Leaders in these countries argue that popularising science encourages people to understand and cooperate with government actions on large-scale problems such as conservation, pollution, irrigation and flooding by man-made reservoirs, sanitation and infectious diseases. They argue that interesting the youth of a country in science increases the country's science manpower and speeds national development. One way of bringing the word about science and technology to the people is through the media of mass communications.

The Depthnews Science Service and Mr Laing's activity in it are themselves interesting results of this newlyawakened interest. PFA, a non-profit agency founded by Asian journalists some ten years ago to improve the standards of the region's media, asked Canada's International Development Research Centre (IDRC) for funds to set up a science feature service within Depthnews. Its aim would be to set the pace for the Asian press in science coverage, which in its opinion (and that of other Asians) had been deficient until then. PFA also asked for an experienced science journalist from the West to set it up and train Asians in the techniques of science journalism.

While it is too early to judge the commercial viability of the science feature service, the initial response of the Asian media has been surprisingly good. Mr Laing has found himself in the ironic position of having to admit that the interest shown by the media in Asia for his service's articles is much greater than he could imagine Canadian editors showing for a comparable service at home.

Among his chief sources of news in the Philippines are weekly news conferences set up specifically for science writers by the University of the Philippines and the National Science Development Board. The conferences were arranged to acquaint science writers with researchers whose work is sponsored jointly by these two organisations. It seems to be succeeding. At a recent conference, about ten media representatives gathered in a small room to hear a pharmacologist talk about work she and her colleagues had been doing in identifying plants with insecticidal qualities that could serve as replacements or alternatives for chemical pesticides. (The other subject, oddly enough, was music, but apparently this was atypical, almost all subjects being scientific).

To encourage attendance, the university has adopted the practices of paying the journalists to attend the con- 
ferences, which are held on Saturday mornings, and of giving them coffee and lunch. The sum is small (the equivalent of about \$9) and although the practice would obviously be unacceptable to the Western press, it may help (and perhaps be necessary) in the Philippines. Dr Joventino Soriano, the coordinator, first introduced the news conferences by holding a four-day science writers' seminar at a mountain-top retreat some miles from Manila. A travelling seminar was also planned in April, when media writers and researchers were to visit villages in three provinces north of Manila to see how science and technology can aid rural areas.

Similar seminars have been held by other organisations. In 1974, the IDRC held one near Manila for science writers. The response was strong from the media in eight regional countries, some of which already had science writers (and one, Korea, highly developed science coverage). In other countries (for example Indonesia) the interest was there but the media structure was not. In 1975, another seminar was held in India, with a similarly strong response from that country and others bordering it. A third seminar planned for June in Nairobi, will be for the East African media.
In March, a month-long Asian Training Course for Leaders in the Promation of Public Understanding in Science, sponsored by UNESCO and the Science Foundation of the Philippines, was concluded in Manila. And in February, as a result of the previously mentioned India seminar, a meeting was held in Colombo, Sri Lanka, on 'Science writing for the people'.

In Sri Lanka, where science writing is largely ignored in English-language newspapers, possibly partly because newsprint shortages make for thin newspapers, the Ministry of Education is reported to be planning on providing scholarships for science writers to obtain university degrees.

At the recent seminar, Professor P. P. G. L. Siriwardene, the ViceChancellor of the University of Sri Lanka, said that science must be written in the vernacular to get to the people. But he added that popularisation of science has been "hamstrung by a lack of funds". In the developing countries, he said, science popularisation should be "an important national venture". The question of language is an important one, as delegates to the IDRC's first seminar noted. In many Asian and African languages there are no words for some scientific concepts. However, in Sri Lanka, as in India, some science does appear in the vernacular-language press.

The Philippines is one of the most enthusiastic promoters of science popularisation among Asian countries. In addition to the emphasis on science news (which is perhaps attractive to editors because of government control of the country's press and the dearth of genuine news stories) there are hundreds of science clubs, which are joined in a federation and hold Youth Science Camps. Science campers visit rural areas to explain science and scientific concepts to farmers and remote villagers, and to replace superstition and myth by rational explanations of natural events. A science quiz, an annual high school contest, has attracted 8,530 regional participants and 292 national participants since 1969 .

In a speech prepared for the course on public understanding held in Manila last March, President Marcos said:

We are belatedly finding out that the harnessing of science and technology is not a mere matter of learning formulae, but a process of cultural transformation itself. It is in this light that I perceive the importance of promoting wide public understanding of science, technology and the environment.

\section{Sifting the sediment}

The staff of La Recherche reports on the prospect of mining sediment in the Red Sea

A CONTRACT was signed on 25 March, in Paris between the Red Sea Commission, represented by its secretary general, Dr Zaki Mustafa, and the Argas Company, represented by its president, Jamil Jawa. The contract, involving FF30 million $(£ 1=F F 8.54)$ is one of a series of agreements on the exploitation of the metalliferous sediment in the Red Sea, which contains $5.8 \%$ zinc, $0.90 \%$ copper and $110 \mathrm{~g}$ of silver for every ton of dry material as well as iron and manganese.

The first agreement between Saudi Arabia and the Sudan, signed in May 1975, was to cooperate in exploiting the mineral resources at the bottom of the Red Sea in the so called 'Common Zone', which lies between the two countries. The resulting Red Sea Commission, which has its headquarters at Jedda, was founded to promote and encourage mining research and any means of exploiting the minerals in the zone. The Commission then called in the Argas Company (The Arabian Geophysics and Surveying Company, a joint venture between the Saudi company Petromine and the French Compagnie Générale de Géophysique).

Two preliminary contracts in March and July 1976 (for FF 15 million and FF8 million respectively) covered geochemical, seismic and aeromagnetic studies. The work to be carried out under the third contract, the one recently signed, will analyse the environment including swell, currents, thermosalinity and biology to ascertain the effect of exploitation on the environment and to determine the conditions necessary for lowering a vertical tube for pumping mud to $2,200 \mathrm{~m}$.

The metal extracted from the sediment would be treated on the spot, and mineral salts and tons of residue extracted from the metal ore would be thrown back into the sea; but what would become of this residue, and what effect it would have on the flora and fauna before settling back on the sea bed remain unanswered questions. A German company, Preussag, has meanwhile been developing the extraction process. A pilot preconcentration plant could be working by 1982, and it will not be known until then whether the project is feasible. Preussag is also under contract from the Red Sea Com- mission, which is providing $\$ 25$ million for six years. The Commission has engaged the services of a French public body in charge of geological and mining research, the BRGM, to coordinate activities and act as technical adviser.

If the project succeeds, it will be the first time that marine sediment has been put to use: other companies engaged in working the ocean bottom are more interested in nodules. The sediment contains important components, however, especially copper, and similar deposits could be found in other parts of the world. Geological studies provide an explanation for the formation of mineral rich sediments: in the Red Sea, where rock outputs cut across the rift, there is a zone of intense volcanic and thermal activity, and the rocks give off large quantities of metallic salt into the water. In the presence of the hot brine frequently found in these regions the metallic salts are eventually precipitated. Thus a sedimentary bed is formed containing enough metal for it to be thought worth while mining out. The first mining will be in the Atlantis II fault, where it is estimated that there would be 850 million tons of sediment, that is $7 \times 10^{6}$ tons of copper. But at least 18 faults are known in the hot brine regions of the Red Sea; some probably do not contain sediment, but others could be extremely profitable. 